\title{
Bio-desaturation and bio-sealing techniques for mitigation of soil liquefaction: a review
}

\author{
Muttaqa Uba, Zango ${ }^{1,2 *}$, Khairul Anuar, Kassim ${ }^{1}$, and Abubakar Sadiq, Mohammed ${ }^{1,3}$ \\ ${ }^{1}$ Faculty of Civil Engineering, UniversitiTeknologi Malaysia81310 Johor Bahru, Johor, Malaysia \\ ${ }^{2}$ Department of Civil Engineering, KUST, WudilP.M.B. 3244 Kano State, Nigeria \\ ${ }^{3}$ Department of Civil and Water Resources Engineering, UnimaidP.M.B. 1069 Maiduguri, Borno \\ State, Nigeria
}

\begin{abstract}
Biogeotechnology is a recent area of study that deals with the improvement of engineering properties of soils in an eco-friendly and sustainable approach through the use of microorganisms. This paper first, reviewed the concept of bio-mediated soil improvement technique, components involved and the roles they played. Two processes of biomediation soil improvement techniques i.e. microbial-induced calcite precipitation (MICP) for producing bio-cement via ureolysis and biodesaturation for generating specifically biogenic nitrogen gas via denitrification, their mechanisms of occurring and factors influencing them were described in details. An overview study was done on soil liquefaction. Conventional methods employed for mitigations of liquefaction hazards were reviewed and their limitations were drawn. The use of the de-saturation process for mitigation of soil liquefaction was adequately addressed. Mitigation of liquefaction using biological processes, in particular, MICP and/or bio-desaturation were introduced. The findings from the previous works have shown that both the two techniques are capable of improving liquefaction resistance of soils. Most of the results have shown that presence of biogenic nitrogen gas in soils treated with denitrifying bacteria is able to induce partial desaturation in the soil which consequently increases the cyclic shear strength, reduces pore water pressure and changes the soil behaviour from compressive to dilatant. Finally, potentials, challenges, and recommendations for future studies were identified.
\end{abstract}

\section{Introduction}

Earthquake and its associated phenomena such as soil liquefaction must occur inevitably but, their effects can be mitigated to reduce loss of life, properties and injuries [1]; [2]. Soil liquefaction being the prime causes of most damages related to earthquake have been given much attention by geotechnical engineers since the earthquakes of 1964 in Alaska - USA and Niigata - Japan [1]. The conventional methods used for mitigating soil liquefaction such as cement grouting, vibro-compaction, drainage dewatering etc. are rated as energyconsuming, expensive and threat to the ecosystem [3]; [4]; For a few years ago, bio-mediated

*Corresponding author: muttaqaubaz@ yahoo.com 
soil improvement technique is becoming more popular for soil improvement such as liquefaction mitigation. Studies have been conducted on the application of the biological process for improving the dynamic response of liquefiable soils, and the outcomes of the research were promising. For instance, [5] had reported the improvement of resistance to liquefaction of poorly graded Ottawa sand which was biologically treated with urease producing bacteria Sporosarcinapasteurii; [4] had utilized various concentration of Sporosarcinapasteurii and its nutrients to increase liquefaction of poorly graded sand; again Feng and Montoya, (2017) have reported that liquefaction resistance increases with the increase in shear wave velocity when two different sandy soils were treated at the same cementation level using bio-mediated soil improvement technique; [3] have improved the liquefaction resistance of sand soil via desaturation process through production of nitrogen biogenic gas; [2] had use biogas and bio-sealing processes to demonstrate liquefaction resistance of sand soil; [7] have used microbial induced denitrification and precipitation (MIDP) by employing denitrifying bacteria to induce desaturation and bio-cementation formation via denitrification process as two stage process.

\section{Bio-mediated Soil Improvement}

A bio-mediated soil improvement system consists of chemical reaction network that is initiated, managed and controlled within soil matrix as a result of biological activity of microorganisms, and the byproducts of the system is capable of improving the engineering properties of soil [8]. The clue of using biological process for soil improvement was first demonstrated in the work done by Mitchell and Santamarina (2005). But it was documented before the work of [9] that microbes can be successfully used in environmental applications such as: stabilization of metals [8], development of biological shields for zonal remediation [8], environmental stabilization of contaminated soils as reported by [8] and encapsulation of hazardous and other contaminants in natural soils and acid mine tailings. Apart from that, a process known as bacteriogenic mineral plugging used for prevention of oil leakages from reserviour was even patented in the U.S. Similarly, bacteria have been utilized in remediation of cracked concrete and masonry structures ([10], [11], [12]).

Biological mediated systems for the improvement of engineering soil properties consist of four components viz chemical reaction network, microorganism and biological activity, process controlling/monitoring and soil improvement phase as represented in figure 1 below[8]. [13] had identified potential bio-geochemical processes commonly utilized in the improvement of soil matrix are identified as bio-mineralization, bio-clogging and biogas generation. 


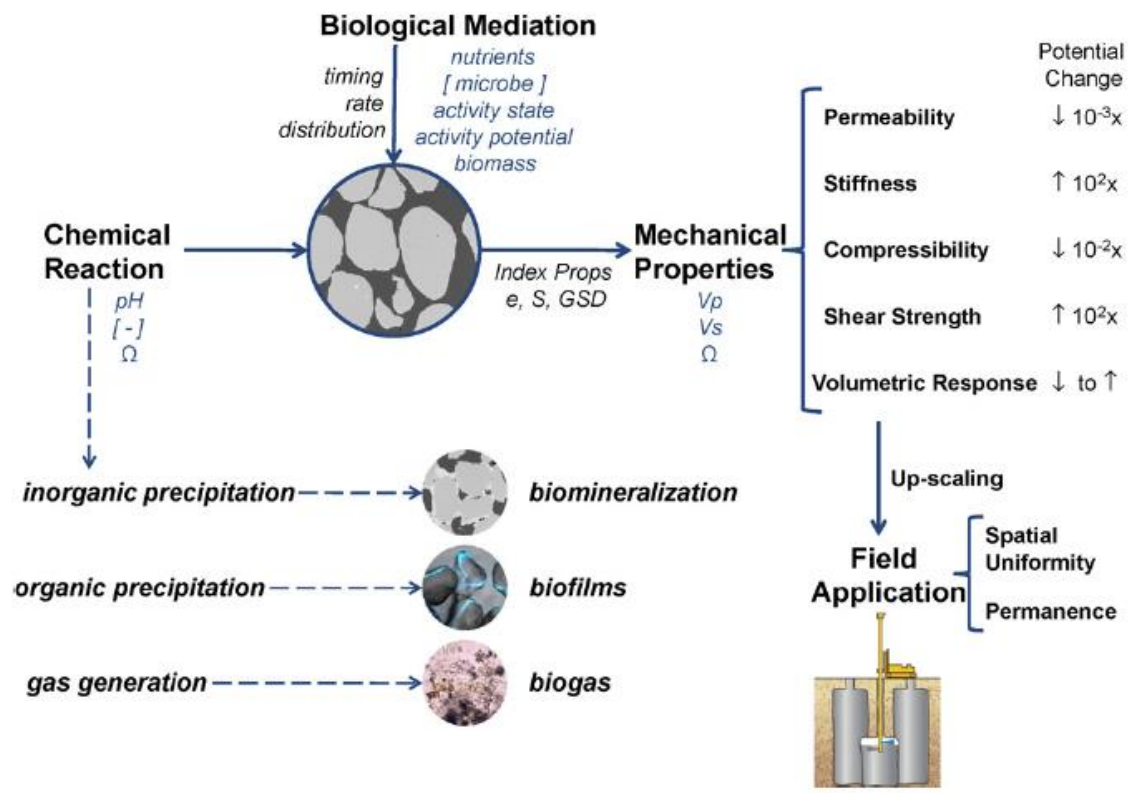

Fig. 1. Overview of Bio-mediated Soil Improvement Systems. [14]

\subsection{Bio-Mineralization}

Bio-mineralization refers to the process of forming minerals precipitates chemically through the activities of living organisms [15]; [16]; [14]. It is a wide spread natural phenomenon in which more than 60 inorganic minerals are reported to have formed as a result of extracellular activities of these microorganisms[17]; [18]. Among minerals formed through this process are: carbonates from invertebrates; silicates from diatoms and algae; phosphates, calcium and carbonate in vertebrates [19].

\subsubsection{Microbial Induced Calcite Precipitation}

Microbial induced calcium carbonate precipitation (MICP) is one of the most important, evident bio-mineralization which is receiving much attention in recent years because of its wide applications in the field of biotechnology, geo-technology and civil engineering [17].The technique mimics the natural Microbial carbonate precipitation (MCP), which is a process that occur as result of chemical reaction associated with the activities of microorganisms [20], [14]. In nature, there are three different ways in which calcium carbonate can be precipitated as reported by [19], viz: photosynthesis through the metabolic activities of cyanobacteria and algae and resulted in removal of carbon dioxide; dissimilatory via denitrification by denitrification bacteria or via sulphate reduction by sulphate reducing bacteria; urea hydrolysis through metabolic activities of urea producing bacteria.

Microbial induced calcite precipitates (MICP) via ureolysis is the commonest and most preferred method of precipitating calcite and its subsequent used in the improvement of soil properties. Among the reasons for choosing urea hydrolysis as preferred method of calcite precipitate formations are: it is simple, direct and easily controlled mechanism that produced high amount of calcium carbonate in a very short period of time [19], [17]. Many microorganisms are found in nature to have the ability to secrete urease enzymes but some particular strains have high level of urease activity[21]; [22]; [23]. Table 1.1 shows some of 
the urease producing bacteria, their sources, urease activity and the amount of calcium carbonate produced.

Table 1. Urease Producing Bacteria from Various Sources and Amount of Urease Activity and Calcite Precipitation (Source: [19])

\begin{tabular}{|c|c|c|c|c|}
\hline Bactria & Isolation Site & $\begin{array}{l}\text { Urease } \\
\text { Activity } \\
(\mathrm{U} / \mathrm{ml}) \\
\end{array}$ & $\begin{array}{l}\text { Calcite } \\
\text { Precipitation }\end{array}$ & $\begin{array}{l}\text { Refere } \\
\text { nces }\end{array}$ \\
\hline Bacillus sp. CR2 & $\begin{array}{l}\text { Mine tailing soil } \\
\text { Urumqi, China }\end{array}$ & 432 & $\begin{array}{ll}232 & \mathrm{mg} / \mathrm{cell} \\
\text { mass } & \end{array}$ & [24] \\
\hline L. sphaericus $\mathrm{CH} 5$ & $\begin{array}{l}\text { Abandoned express } \\
\text { way and abandoned } \\
\text { mining sites } \\
\text { Gangwondo, Korea }\end{array}$ & - & $980 \mathrm{mg} / 100 \mathrm{ml}$ & {$[25]$} \\
\hline Sporosarcinapasteurii & $\begin{array}{l}\text { Pehnotypic Mutant } \\
\text { Strain }\end{array}$ & 550 & - & [26] \\
\hline $\begin{array}{l}\text { B. pasteurii NCIM } \\
2477\end{array}$ & $\begin{array}{l}\text { Culture obtained } \\
\text { from NCIM, Pune, } \\
\text { India }\end{array}$ & 18 & - & [27] \\
\hline K. flava CRl & $\begin{array}{l}\text { Mining ore soil, } \\
\text { Urumqi, China }\end{array}$ & 472 & - & [28] \\
\hline $\begin{array}{l}\text { Bacillus } \\
\text { megateriumSS3 }\end{array}$ & 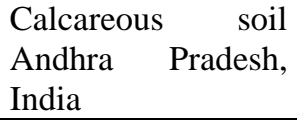 & 690 & $187 \mathrm{mg} / 100 \mathrm{ml}$ & $\begin{array}{l}{[29],} \\
{[30]}\end{array}$ \\
\hline B. thuringiensis & $\begin{array}{lr}\text { Calcareous } & \text { soil } \\
\text { Andhra Pradesh, } \\
\text { India }\end{array}$ & 620 & $167 \mathrm{mg} / 100 \mathrm{ml}$ & [29] \\
\hline Holomonassp & $\begin{array}{l}\text { Mining tailing, } \\
\text { China }\end{array}$ & 3745 & - & {$[31]$} \\
\hline
\end{tabular}

Biological precipitation of calcium carbonate through ureolysis occurs as results of secretion of urease enzyme which help in hydrolyzing urea present in the system into ammonia and carbon dioxide [19]; [32]; [33]. The ammonia further dissolved in water to liberate ammonium ion $\left(\mathrm{NH}_{4}{ }^{+}\right)$and hydroxyl ion $\left(\mathrm{OH}^{-}\right)$while the carbon dioxide dissolved in water to form bicarbonate $\left(\mathrm{HCO}_{3}^{-}\right)$. The $\mathrm{OH}$ - ion formed from dissolution of $\mathrm{NH}_{3}$ into $\mathrm{NH}_{4}{ }^{+}$resulted in the increase in $\mathrm{pH}$ of the medium which further lead to decomposition of bicarbonate $\left(\mathrm{HCO}_{3}^{-}\right)$into carbonate $\left(\mathrm{CO}_{3}{ }^{2-}\right)$. In the presence of calcium ion $\left(\mathrm{Ca}^{2+}\right)$ present in the system, the carbonate reacts with calcium to form precipitate of calcium carbonate [34]; [33]; [20]. The chemical equations of the mechanism are shown in equ (1) through (5) and the overall equation is shown in equ (6) of the process is shown below:

$$
\begin{aligned}
& \mathrm{CO}\left(\mathrm{NH}_{2}\right)_{2}+\mathrm{H}_{2} \mathrm{O} \rightarrow 2 \mathrm{NH}_{3}+\mathrm{CO}_{2} \\
& 2 \mathrm{NH}_{3}+2 \mathrm{H}_{2} \mathrm{O} \rightarrow 2 \mathrm{NH}_{4}^{+}+2 \mathrm{OH}^{-} \\
& \mathrm{CO}_{2}+\mathrm{H}_{2} \mathrm{O} \rightarrow \mathrm{HCO}_{3}^{-}+\mathrm{H}^{+} \\
& \mathrm{HCO}_{3}^{-}+\mathrm{H}^{+}+2 \mathrm{OH}^{-} \leftrightarrow \mathrm{CO}_{3}^{2-}+2 \mathrm{H}_{2} \mathrm{O} \\
& \mathrm{Ca}^{2+}+\mathrm{CO}_{3}^{2-} \rightarrow \mathrm{CaCO}_{3} \downarrow \\
& \mathrm{CO}\left(\mathrm{NH}_{2}\right)_{2}+\mathrm{H}_{2} \mathrm{O}+\mathrm{Ca}^{2+} \rightarrow 2 \mathrm{NH}_{4}^{+}+\mathrm{CaCO}_{3} \downarrow
\end{aligned}
$$

Urease activity of bacteria can be affected by many environmental and other situational conditions. These factors can either increase the efficiency of the urease activity or inhibit it 
[15]. Among the situational factors are: type of bacteria, bacterial concentration, growth and storage, while the environmental factors are: $\mathrm{pH}$, temperature, presence of other microorganisms, availability of other compounds, substrates and products concentrations [35].

\subsection{Microbial Denitrification Process}

Denitrification, otherwise known as microbial induced dissimilatory is a biochemical process of producing biogas and calcium carbonate precipitates through metabolic activities of denitrifying bacteria on nitrates and organic chemical compounds known as electron donors [7]; [13]. The biogases produce in denitrification process are nitrogen $\left(\mathrm{N}_{2}\right)$, carbon dioxide (CO2) [36], [7]. Equ (7) to equ (9) show typical denitrification reactions when different organic compounds are used as electron acceptors:

$$
\begin{gathered}
5 \mathrm{CH}_{2} \mathrm{OH}+6 \mathrm{NO}_{3}^{-} \rightarrow 3 \mathrm{~N}_{2}+5 \mathrm{CO}_{2}+7 \mathrm{H}_{2} \mathrm{O}+6 \mathrm{OH}^{-} \\
5 \mathrm{C}_{2} \mathrm{H}_{5} \mathrm{OH}+12 \mathrm{NO}_{3}^{-} \rightarrow 6 \mathrm{~N}_{2}+10 \mathrm{CO}_{2}+9 \mathrm{H}_{2} \mathrm{O}+12 \mathrm{OH}^{-} \\
5 \mathrm{C}_{2} \mathrm{H}_{5} \mathrm{OH}+12 \mathrm{NO}_{3}^{-} \rightarrow 4 \mathrm{~N}_{2}+10 \mathrm{CO}_{2}+\mathrm{H}_{2} \mathrm{O}+13 \mathrm{OH}^{-}
\end{gathered}
$$

The nitrogen gas produced in the equations above is the most suitable for this purpose as it is chemically inert, low solubility in water, most abundant in the atmosphere, non-toxic and harmful to the environment [37], [38], [36] while the CO2 is found to be highly soluble in water and thus, could not be used in the improvement of or desaturation of saturated soil [38].

In an environment containing electron donors and nitrates, two possible reductions could occur which give different products during denitrifications. The two mechanisms of nitrates reduction are ammonification in which the product is ammonium ion; or respiratory denitrification which gives intermediate products of nitric oxide, nitrous oxide and final product of nitrogen gas [36]. The figure 1.2 below shows the mechanisms:

\section{Ammonification}

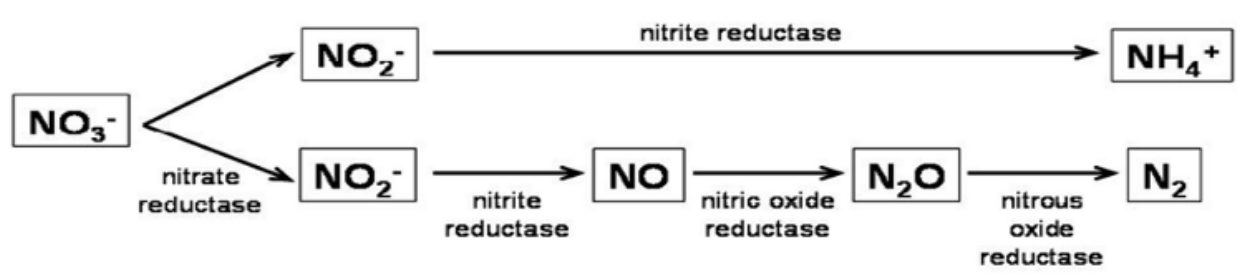

\section{Respiratory denitrification}

Fig. 2. Nitrite and Nitrate Reduction. [36]

\subsubsection{Factors Affecting Denitrification Process}

Microbial denitrification like any other enzymatic reactions are affected upon by many environmental factors [13]. These factors influence the rate of denitrification process and products formed at the end or during the process [39], [40]. Among the factors identified are pH [39], [40], [41]; nitrates concentration [40], [42] and medium composition [43], [40]. Other environmental factors are presence of oxygen gas [39], pore space geometry, moisture content [13] and temperature [40]. 


\section{Soil Liquefaction Susceptibility}

Soil liquefaction is one of the major causes of devastating structural damage aftermath of an earthquake. Soil liquefied as a result of loss of strength or stiffness associated with earthquake and this leads to the structural failures such as settlement of buildings, landslides, dams' failure [44]. Soil liquefaction also can cause less damaging effect such as settlement and flooding large areas, ground deformation, lateral deformation of slightly inclined ground [45] etc. Soil liquefaction has first drawn the attention of engineers after Nigata - Japan earthquake in 1964. This earthquake as a result of spread soil liquefaction lead to the damage of building much worth than 1 Billion dollars [1].

Soil liquefaction is associated with recent geologic deposit; and sandy soil is the most susceptible to liquefaction. Other type of soils that are equally prone to liquefaction are any granular saturated soils without or little clay contents [46]. These soils could be some silts, silty sands, and even gravels. Based on laboratory, field measurements and observation after liquefaction induced earthquake, a range of grain size had been come up for liquefactionprone soil [4]; [47]. Figure 1.3 below shows the grain size distribution of most liquefiable sand.

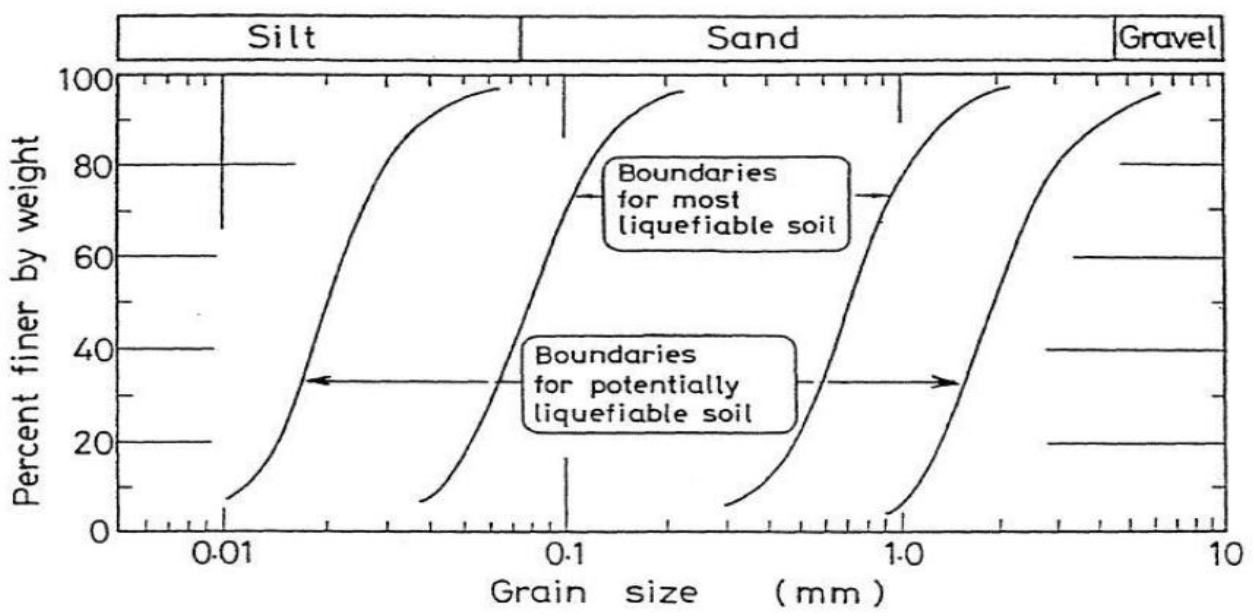

Fig. 3. Grain Size Distribution of Most Liquefiable Soils. [47]

\subsection{Methods of Mitigating Soil Liquefaction}

Conventionally, liquefiable soils are improved by either densification technique such vibro compaction, vibro floatation, or injection of binding agent like cement grouting, epoxy or silicates [5]. These conventional methods of improving liquefied soil are however not feasible in sites close to existing structures [45]. Table 2 below gives a summary of various conventional liquefaction mitigation methods together with their advantages and limitations. 
Table 2. Summary of Conventional Soil Liquefaction Mitigation Techniques.

\begin{tabular}{|c|c|c|c|c|}
\hline Technique & $\begin{array}{l}\text { Parameters } \\
\text { Modify }\end{array}$ & Methods & Advantages & Limitations \\
\hline Densification & $\begin{array}{l}\text { - Increases } \\
\text { shear } \\
\text { strength } \\
\text { and } \\
\text { stiffness }\end{array}$ & $\begin{array}{l}\text { - Vibro compaction } \\
\text { - Dynamic } \\
\text { compaction } \\
\text { - Blast } \\
\text { densification }\end{array}$ & $\begin{array}{l}\text { - Fairly } \\
\text { inexpensive } \\
\text { - Sometimes can } \\
\text { be applied to } \\
\text { nearby structures }\end{array}$ & $\begin{array}{l}\text { - Induce } \\
\text { ground } \\
\text { settlement } \\
\text { - Cannot be } \\
\text { used in } \\
\text { finer } \\
\text { ground } \\
\text { materials } \\
\text { such as silts }\end{array}$ \\
\hline Reinforcement & $\begin{array}{l}\text { - Improves } \\
\text { shear } \\
\text { strength } \\
\text { and } \\
\text { stiffness } \\
\text { - Reduces } \\
\text { drainage } \\
\text { path } \\
\text { - Decrease } \\
\text { pore } \\
\text { water } \\
\text { pressure }\end{array}$ & $\begin{array}{l}\text { - Stone columns } \\
\text { - Jet grouting }\end{array}$ & $\begin{array}{l}\text { - Popular for use in } \\
\text { new structures } \\
\text { - Reinforces the } \\
\text { soil } \\
\text { - Enhances lateral } \\
\text { earth pressure }\end{array}$ & $\begin{array}{l}\text { - Cannot be } \\
\text { used in } \\
\text { existing } \\
\text { built areas } \\
\text { - Expensive } \\
\text { - Cannot be } \\
\text { used below } \\
\text { structures }\end{array}$ \\
\hline Drainage & $\begin{array}{l}\text { - Reduce } \\
\text { generatio } \\
\mathrm{n} \quad \text { of } \\
\text { excess } \\
\text { pore } \\
\text { water } \\
\text { pressure }\end{array}$ & $\begin{array}{l}\text { - Stone columns } \\
\text { - Gravel drains } \\
\text { - Prefabricated } \\
\text { vertical drains }\end{array}$ & $\begin{array}{l}\text { - Decrease the } \\
\text { chance of build- } \\
\text { up excess pore } \\
\text { water pressure }\end{array}$ & $\begin{array}{l}\text { - Cannot be } \\
\text { installed } \\
\text { beneath } \\
\text { existing } \\
\text { structures } \\
\text { - Cannot } \\
\text { minimize } \\
\text { seismic } \\
\text { settlement }\end{array}$ \\
\hline Solidification & $\begin{array}{l}\text { - Aggregat } \\
\text { es and } \\
\text { solidify } \\
\text { the soil }\end{array}$ & $\begin{array}{l}\text { - } \text { Permeation } \\
\text { grouting such as } \\
\text { chemical and } \\
\text { particulates } \\
\text { - Soil mixing }\end{array}$ & $\begin{array}{l}\text { - Chemical of low } \\
\text { viscosity can be } \\
\text { used }\end{array}$ & $\begin{array}{l}\text { - Very } \\
\text { expensive } \\
\text { - Chemical } \\
\text { could be } \\
\text { toxic and } \\
\text { harmful }\end{array}$ \\
\hline
\end{tabular}

\subsection{Desaturation Technique for Mitigation of Soil Liquefaction}

It has been established that the strength and behavior of soils improved as a result of decrease in degree of saturation [49]. For instance, it has been demonstrated through experimental works that cyclic resistance of sand increases tremendously with the small decrease in degree of saturation [50], [51] [52]. The authors also determined that the improvement in resistance 
to liquefaction is more when the initial effective confining stress is higher. It has also been found that initial pore water pressure affects cyclic resistance of unsaturated soils [49].

Traditional techniques used for desaturation are mostly based on dewatering via pumping. These techniques are effective in liquefaction mitigation but they have limitations of posing the risk of causing excessive settlement beneath the existing structure and cost associated with pumping constantly, thus newer methods of desaturation are currently being employed for mitigating soil liquefaction [49].

The newer methods include: electrolysis which involve the use of electric current in the ground to break the pore water into hydrogen and oxygen gas. The method is found to increase the cyclic resistance of Ottawa sand, and the desaturation have not been reserved even after long period of time [53]. Another method of desaturation is by use of chemical most especially sodium perborate [54]. The sodium perborate reacts with water to produce oxygen gas bubbles, which able to reduce the degree of saturation of sand down to $40 \%$ [54]. Pressurized air from compaction piles were also been employed to desaturate soil and eventually increase the cyclic resistance of the soil [55].

\subsection{Bio-Mediated Techniques for Soil Liquefaction}

Many researches were conducted on the use of microbial induced calcite precipitation (MICP) as viable method for improving liquefaction resistance of soils as well as using biodesaturation method (using biogenic gas) via denitrification process.

\subsubsection{Mitigation of Soil Liquefaction via Bio-Desaturation Technique}

It was demonstrated that biogas could be generated from denitrification process. [56] had used denitrifying bacteria to induce desaturation in sand, which consequently reduced the risk of soil liquefaction. Many other researchers such as [57], [13], [40], [3], [7] had employed various denitrifying bacteria to induce desaturation in soil through the generation of chemically inert nitrogen gas. The method was found to be effective for increasing the cyclic resistance of sand. The effectiveness of the gas generated were improved in many research works by bio-sealing the gas bubbles through production of calcium carbonate precipitates ([57]; [13]; [7].

\subsubsection{Mitigation of Soil Liquefaction via MICP Technique}

It had been established that liquefaction resistance of soils treated via MICP technique tend increase [5];[58]. Many researches have reported improvement of various parameters such as monotonic and cyclic shear strength, stiffness, vertical settlement, pore water pressure, dilative behavior [5];[58]; [4]; [45].

\section{Conclusion and Challenges Regarding Bio-Mediated Soil Improvement for Mitigating Soil Liquefaction}

\subsection{Challenges in Bio-mediated Soil Improvement for Liquefaction Mitigation}

Bio-mediated soil improvement is a new and evolving technique which is still at laboratory scale. Therefore, up-scaling the technique to the field scale has remain one of the challenging tasks facing the feasibility of the technique; though, bench scale laboratory and in-situ experiments were attempted by some authors. 


\subsection{Conclusion}

Bio-mediated soil improvement is a promised future technique for improving engineering properties of soils. The technique has shown to be effective especially for mitigation of soil liquefaction, though it is still at laboratory scale. The results and observations made with regard to the application of bio-desaturation and microbial calcite precipitation for soil mitigation can be captured in the following points:

$>$ Urea hydrolysis is the most popular approach for inducing calcium carbonate precipitates for bio-mediated soil improvement, soil liquefaction mitigation inclusive

$>$ Denitrification unlike ureolysis is another approach capable of mitigating liquefaction susceptibility via two stages processes: bio-desaturation through production of biogenic gas and bio-cementation technique through production of calcium carbonate precipitates. Denitrification process produces less harzadous byproducts than urea hydrolysis but the process is slower.

$>$ Utilization of denitrification process as desaturation technique while urea hydrolysis for MICP could be an efficient approach for mitigation soil liquefaction

$>$ MICP technique via ureolysis have found to improve resistance to liquefaction of soil through increased in static strength, stiffness; through increased in dynamic properties of soil such as cyclic stress ratio (CSR); through decreased in pore water pressure and settlement and also through improvement in dilantancy of the treated soils.

$>$ Non-destructive soil columns test have shown that biogenic gas produced due to denitrification process was able to reduce the degree of saturation in soils. The desaturation occurs mostly within 1 - 3 days.

$>$ Reduction in the degree of saturation was found to significantly increased the resistance of soil to liquefaction.

$>$ Biogas bubbles produced due to denitrification is more stable when the soils are biocemented via MICP technique

$>$ Distribution of biogas is affected by the effective over burden stress. At deeper height from the top, the bubbles becomes very tiny and immovable.

$>$ Microscopy analysis results through computer tomography (CT) scan have indicated the higher the biogas produced the lower the degree of saturation would be achieved.

> Non-destructive geophysical techniques such as shear wave velocity, P-wave velocity provide a means for monitoring biomediated soil improvement process.

$>$ There is need for conducting cyclic stress test on soil samples subjected to different degree of saturation due to generated biogas.

$>$ There is also need to determine the optimum parameters for biological treatment of soil using denitrification process under continous flow conditions

$>$ It is also very imperative and interesting to investigate the feasibility of either stimulating both insitu denitrifying and ureolytic bacteria at the same time or simultaneous bioaugementing of denitrifying and urease producing bacteria. This combination will have advantage of producing both biogenic gas for desaturation of soils and calcite precipitate for cementating the soils particles. Another advantage is reduction of environmental contamination. 


\section{References}

1. S. L. Kramer, Geotechnical Earthquake Engineering. Upper Saddle River, New Jersey USA: Prentice Hall, 1996.

2. Y. Li, "Mitigation of sand liquefaction using in situ production of biogas with biosealing," pp. 1-48, 2014.

3. J. He and J. Chu, "Undrained Responses of Microbially Desaturated Sand under Monotonic Loading," J. Geotech. Geoenvironmental Eng., vol. 140, no. 5, p. 4014003, 2014.

4. H. Zhiguang, C. Xiaohui, and M. Qiang, "An experimental study on dynamic response for MICP strengthening liquefiable sands," vol. 15, no. 4, pp. 673-679, 2016.

5. B. M. Montoya, J. T. DeJong, and R. W. Boulanger, "Dynamic response of liquefiable sand improved by microbial-induced calcite precipitation," Géotechnique, vol. 63, no. 4, pp. 302-312, 2013.

6. K. Feng and B. M. Montoya, "Quantifying Level of Microbial-Induced Cementation for Cyclically Loaded Sand," J. Geotech. Geoenvironmental Eng., vol. 143, no. 6, p. 6017005, 2017.

7. S. T. O’Donnell, B. E. Rittmann, and E. Kavazanjian, "MIDP: Liquefaction Mitigation via Microbial Denitrification as a Two-Stage Process. I: Desaturation," J. Geotech. Geoenvironmental Eng., vol. 143, no. 12, p. 4017094, 2017.

8. J. T. DeJong, M. B. Fritzges, and K. Nüsslein, "Microbially Induced Cementation to Control Sand Response to Undrained Shear," J. Geotech. Geoenvironmental Eng., vol. 132, no. 11, pp. 1381-1392, 2006.

9. J. K. Mitchell and J. C. Santamarina, "Biological Considerations in Geotechnical Engineering," J. Geotech. Geoenvironmental Eng., vol. 131, no. 10, pp. 1222-1233, 2005 .

10. C. Qian, R. Wang, L. Cheng, and J. Wang, "Theory of microbial carbonate precipitation and its application in restoration of cement-based materials defects," Chinese J. Chem., vol. 28, no. 5, pp. 847-857, 2010.

11. V. Achal, A. Mukerjee, and M. Sudhakara Reddy, "Biogenic treatment improves the durability and remediates the cracks of concrete structures," Constr. Build. Mater., vol. 48, pp. 1-5, 2013.

12. W. De Muynck, D. Debrouwer, N. De Belie, and W. Verstraete, "Bacterial carbonate precipitation improves the durability of cementitious materials," Cem. Concr. Res., vol. 38, no. 7, pp. 1005-1014, 2008.

13. S. Wu, Mitigation of liquefaction hazards using the combined biodesaturation and bioclogging method. Iowa State University: Graduate Theses and Dissertations. 14728., 2015 .

14. J. T. DeJong, B. M. Mortensen, B. C. Martinez, and D. C. Nelson, "Bio-mediated soil improvement," Ecol. Eng., vol. 36, no. 2, pp. 197-210, 2010.

15. S. Stocks-Fischer, J. K. Galinat, and S. S. Bang, "Microbiological precipitation of 
CaCO3," Soil Biol. Biochem., vol. 31, no. 11, pp. 1563-1571, 1999.

16. A. J. Phillips, R. Gerlach, E. Lauchnor, A. C. Mitchell, A. B. Cunningham, and L. Spangler, "Engineered applications of ureolytic biomineralization: A review," Biofouling, vol. 29, no. 6, pp. 715-733, 2013.

17. N. K. Dhami, M. S. Reddy, and M. S. Mukherjee, "Biomineralization of calcium carbonates and their engineered applications: A review," Front. Microbiol., vol. 4, no. OCT, pp. 1-13, 2013.

18. B. Lian, Q. Hu, J. Chen, J. Ji, and H. H. Teng, "Carbonate biomineralization induced by soil bacterium Bacillus megaterium," Geochim. Cosmochim. Acta, vol. 70, no. 22, pp. 5522-5535, 2006.

19. P. Anbu, C. H. Kang, Y. J. Shin, and J. S. So, "Formations of calcium carbonate minerals by bacteria and its multiple applications," Springerplus, vol. 5, no. 1, pp. 1-26, 2016.

20. M. Umar, K. A. Kassim, and P. C. T. Kenny, "Biological process of soil improvement in civil engineering: A review," J. Rock Mech. Geotech. Eng., vol. 8, no. 5, pp. 767-774, 2016.

21. F. Hammes, N. Boon, J. De Villiers, W. Verstraete, S. D. Siciliano, and J. De Villiers, "Strain-Specific Ureolytic Microbial Calcium Carbonate Precipitation Strain-Specific Ureolytic Microbial Calcium Carbonate Precipitation," Appl. Environ. Microbiol., vol. 69, no. 8, pp. 4901-4909, 2003.

22. A. C. Mitchell and F. G. Ferris, "The coprecipitation of Sr into calcite precipitates induced by bacterial ureolysis in artificial groundwater: Temperature and kinetic dependence," Geochim. Cosmochim. Acta, vol. 69, no. 17, pp. 4199-4210, 2005.

23. G. D. O. Okwadha and J. Li, "Optimum conditions for microbial carbonate precipitation," Chemosphere, vol. 81, no. 9, pp. 1143-1148, 2010.

24. V. Achal and X. Pan, "Influence of calcium sources on microbially induced calcium carbonate precipitation by Bacillus sp. CR2," Appl. Biochem. Biotechnol., vol. 173, no. 1, pp. 307-317, 2014.

25. C. H. Kang, J. H. Choi, J. G. Noh, D. Y. Kwak, S. H. Han, and J. S. So, "Microbially Induced Calcite Precipitation-based Sequestration of Strontium by Sporosarcina pasteurii WJ-2," Appl. Biochem. Biotechnol., vol. 174, no. 7, pp. 2482-2491, 2014.

26. V. Achal, A. Mukherjee, P. C. Basu, and M. S. Reddy, "Strain improvement of Sporosarcina pasteurii for enhanced urease and calcite production," J. Ind. Microbiol. Biotechnol., vol. 36, no. 7, pp. 981-988, 2009.

27. D. Sarda, H. S. Choonia, D. D. Sarode, and S. S. Lele, "Biocalcification by Bacillus pasteurii urease: A novel application," J. Ind. Microbiol. Biotechnol., vol. 36, no. 8, pp. $1111-1115,2009$.

28. V. Achal, A. Mukherjee, and M. S. Reddy, "Effect of calcifying bacteria on permeation properties of concrete structures," J. Ind. Microbiol. Biotechnol., vol. 38, no. 9, pp. 12291234, 2011.

29. N. K. Dhami, M. S. Reddy, and A. Mukherjee, "Bacillus megaterium mediated mineralization of calcium carbonate as biogenic surface treatment of green building 
materials," World J. Microbiol. Biotechnol., vol. 29, no. 12, pp. 2397-2406, 2013.

30. N. K. Dhami, M. S. Reddy, and A. Mukherjee, "Synergistic role of bacterial urease and carbonic anhydrase in carbonate mineralization," Appl. Biochem. Biotechnol., vol. 172, no. 5, pp. 2552-2561, 2014.

31. V. Achal, X. Pan, and D. Zhang, "Bioremediation of strontium (Sr) contaminated aquifer quartz sand based on carbonate precipitation induced by Sr resistant Halomonas sp.," Chemosphere, vol. 89, no. 6, pp. 764-768, 2012.

32.F. Hammes, W. Verstraete*, and W. Verstraete, "Key roles of $\mathrm{pH}$ and calcium metabolism in microbial carbonate precipitation," Re/Views Environ. Sci. Bio/Technology, vol. 1, no. Morita 1980, pp. 3-7, 2002.

33. R. A. Burne and Y. Y. M. Chen, "Bacterial ureases in infectious diseases," Microbes and Infection, vol. 2, no. 5. pp. 533-542, 2000.

34. S. Castanier, G. Le M, J. Perthuisot, and G. Le Metayer-Levrel, "Bacterial roles in the precipitation of carbonate minerals," Microb. sediments, pp. 32-39, 2000.

35. S. S. B. F.D. Meyer, S. Bang, S. Min, L.D. Stetler, "Microbiologically-Induced Soil Stabilization: Application of," Geo-Frontiers, pp. 4002-4011, 2011.

36. V. Rebata-landa, J. C. Santamarina, and M. Asce, "Mechanical Effects of Biogenic Nitrogen Gas Bubbles in Soils," no. February, pp. 128-137, 2012.

37. J. He, J. Chu, and V. Ivanov, "Remediation of Liquefaction Potential of Sand Using the Biogas Method," Geo-Congress 2013@sStability Perform. ..., pp. 879-887, 2013.

38. J. He, J. Chu, and V. Ivanov, "Mitigation of liquefaction of saturated sand using biogas," vol. 63, no. 4, 2013.

39. S. Saleh-Lakha et al., "Effect of $\mathrm{pH}$ and temperature on denitrification gene expression and activity in Pseudomonas mandelii," Appl. Environ. Microbiol., vol. 75, no. 12, pp. 3903-3911, 2009.

40. J. He, "Mitigation of liquefaction of sand using microbial methods," pp. 879-887, 2013.

41. K. Šimek, J. Nedoma1, T. P. Jakob Pernthaler, and J. R. Dolan, “Altering the balance between bacterial production and protistan," Antonie Van Leeuwenhoek, vol. 81, pp. 453463, 2002.

42. L. A. van Paassen, R. Ghose, T. J. M. van der Linden, W. R. L. van der Star, and M. C. M. van Loosdrecht, "Quantifying Biomediated Ground Improvement by Ureolysis: Large-Scale Biogrout Experiment," J. Geotech. Geoenvironmental Eng., vol. 136, no. 12, pp. 1721-1728, 2010.

43. M. Blaszczyk, "Effect of Medium Composition on the Denitrification of Nitrate by Paracoccus denitrificans Effect of Medium Composition on the Denitrification of Nitrate by Paracoccus denitrificans," vol. 59, no. 11, pp. 3951-3953, 1993.

44. M. Simatupang and M. Okamura, "Liquefaction resistance of sand remediated with carbonate precipitation at different degrees of saturation during curing," Soils Found., vol. 57, no. 4, pp. 619-631, 2017.

45. E. Kavazanjian and S. T. O’Donnell, “Mitigation of Earthquake-Induced Liquefaction via 
Microbial Denitrification: A Two-Phase Process," Ifcee 2015, pp. 2286-2295, 2015.

46. R. W. Boulanger and I. M. Idriss, "Liquefaction Susceptibility Criteria for Silts and Clays," J. Geotech. Geoenvironmental Eng., vol. 132, no. 11, pp. 1413-1426, 2006.

47. H. Tsuchida, "Prediction of liquefaction of sandy deposits and countermeasures to liquefaction hazards," in Proceedings of the Annual meeting of the Port and Harbour Research Institute (in Japanese), 1970, p. 3.1-3.33.

48. Y. Huang and Z. Wen, "Recent developments of soil improvement methods for seismic liquefaction mitigation,” Nat. Hazards, vol. 76, no. 3, pp. 1927-1938, 2015.

49. S. O’Donnell, Mitigation of Earthquake-Induced Soil Liquefaction via Microbial Denitrification: A Two-Stage Process, no. March. ARIZONA STATE UNIVERSITY, 2016.

50. Y. Tsukamoto, S. Kawabe, J. Matsumoto, and S. Hagiwara, "Cyclic resistance of two unsaturated silty sands against soil liquefaction," Soils Found., vol. 54, no. 6, pp. 10941103, 2014.

51.J. Yang, S. Savidis, and M. Roemer, "Evaluating liquefaction strength of partially saturated sand," J. Geotech. Eng. Div., vol. 130, no. 9, pp. 975-979, 2004.

52. M. Simatupang, Y. Kosaka, and M. Okamura, "Effects of Degree of Saturation on Liquefaction Resistance of Sand Improved with Enzymatic Calcite Precipitation," no. Micce, 2015.

53. M. K. Yegian, E. Eseller-Bayat, A. Alshawabkeh, and S. Ali, "Induced-partial saturation for liquefaction mitigation: experimental investigation," J. Geotech. Geoenvironmental Eng., vol. 133, no. 4, pp. 372-380, 2007.

54. E. Eseller-bayat, M. K. Yegian, and A. Alshawabkeh, "Liquefaction Response of Partially Saturated Sands. I : Experimental Results,” J. Geotech. Geoenvironmental Eng., vol. 139, no. 6, pp. 863-871, 2013.

55. M. Okamura, M. Ishihara, and K. Tamura, "Degree of Saturation and Liquefaction Resistances of Sand Improved with Sand Compaction Pile," J. Geotech. Geoenvironmental Eng., vol. 132, no. 2, pp. 258-264, 2006.

56. V. Rebata-Landa and J. C. Santamarina, "Mechanical Effects of Biogenic Nitrogen Gas Bubbles in Soils," J. Geotech. Geoenvironmental Eng., vol. 138, no. 2, pp. 128-137, 2012.

57. Y. Li, "Mitigation of sand liquefaction using in situ production of biogas with biosealing," 2014.

58. K. Feng and B. M. Montoya, "Drained Shear Strength of MICP Sand at Varying Cementation Levels," Ifcee, pp. 2242-2251, 2015. 